\title{
MODEL BIAYA PRODUKSI BIODIESEL BERBASIS MINYAK SAWIT
}

\section{A Production Cost Modelling of Palm Oil Base Biodiesel}

\author{
Meilita Tryana Sembiring*, Sukardi, Ani Suryani, dan Muhammad Romli \\ Departemen Teknologi Industri Pertanian, Fakultas Teknologi Pertanian, Institut Pertanian Bogor \\ Kampus IPB Darmaga, Jl. Raya Darmaga Bogor 16002 \\ *e-mail: meilita tryana@yahoo.co.id
}

Diterima: 9 Februari 2015, revisi akhir: 5 Juni 2015 dan disetujui untuk diterbitkan: 12 Juni 2015

\begin{abstract}
ABSTRAK
Biodiesel adalah sumber energi terbarukan di Indonesia yang diatur penggunaannya oleh pemerintah dalam bentuk kebijakan mandatori pencampuran biodiesel dengan solar (biosolar). Produksi biodiesel di Indonesia tidak berkembang (kebutuhan 3.4 juta kiloliter namun total produksi nasional hanya 1.703 kiloliter). Hal tersebut disebabkan harga jual (mengacu Mean of Platts Singapore) yang selalu lebih rendah dibandingkan biaya pokok produksi. Produksi biodiesel dipengaruhi oleh bahan baku dan teknologi proses, sehingga perlu dilakukan pemodelan produksi biodiesel sebagai landasan dalam menentukan kebijakan pendukung harga jual biodiesel. Tujuan penelitian ini adalah mengidentifikasi bahan baku, teknologi proses, dan memodelkan struktur biaya produksi biodiesel berbasis minyak sawit. Identifikasi bahan baku dilakukan dengan studi literatur dan survei lapangan ke produsen biodiesel. Identifikasi teknologi proses dilakukan dengan survei lapangan dan perhitungan neraca massa dengan teknologi Grand Inizio untuk mendapatkan jumlah rendemen dari masing-masing bahan baku. Selanjutnya kajian biaya produksi dilakukan berdasarkan spesifikasi bahan baku dan teknologi proses dengan pendekatan heuristik. Jenis dan spesifikasi minyak sawit yang banyak digunakan produsen di Indonesia adalah Crude Palm Oil (CPO) ALB $<5 \%$, Refined Palm Oil (RPO) ALB $<5 \%$, Refined Oil ALB $<1 \%$, Palm Fatty Acid Distillated (PFAD) ALB 90\%. Teknologi proses yang digunakan adalah transesterifikasi untuk kadar $A L B<1 \%$ dan esterifikasitransesterifikasi untuk kadar $\mathrm{ALB}<5 \%$. Rendemen yang dihasilkan untuk $1000 \mathrm{~kg}$ bahan baku adalah CPO $1051.75 \mathrm{~kg}$, RPO dan PFAD $975.94 \mathrm{~kg}$, Refined Oil $973.81 \mathrm{~kg}$ dengan pendekatan teknologi Grand Inizio. Model biaya produksi merepresentasikan total biaya produksi yang dipengaruhi oleh biaya Inside Battery Limit, Outside Battery Limit, biaya umum dan nilai tambah gliserol.
\end{abstract}

\section{Kata Kunci: Biodiesel, asam lemak bebas, pemodelan, minyak sawit, biaya produksi}

\section{ABSTRACT}

Biodiesel is a renewable energy source in Indonesia of which the use is regulated by the government in the form of mandatory policy of biodiesel and diesel fuel blending. The production of biodiesel in Indonesia is not developed (the need is 3.4 million kiloliters but the total national production is only 1,703 kiloliters). It is because the selling price (referring to Mean of Platts Singapore) is always lower than the production cost. Biodiesel production is influenced by raw materials and process technology, so it needs to be conducted biodiesel production modeling as a basis in determining the supporting policies of biodiesel selling price. The purpose of this study was to identify the raw materials, process technology, and modeling the production cost structure of palm oil-based biodiesel. Identification of raw materials was conducted by literature study and field survey to biodiesel producers. Identification of process technology was conducted by field survey and mass balance calculation using Grand Inizio technology to get the number of yield of each raw material. Then, production cost study was based on the specifications of raw materials and process technology with heuristic approach. Types and specifications of palm oil widely used by Indonesian producers were Crude Palm Oil (CPO) 
FFA $<5 \%$, Refined Palm Oil (RPO) FFA $<5 \%$, Refined Oil FFA $<1 \%$, Palm Fatty Acid Distillated (PFAD) FFA 90\%. The technology process used was transesterification for FFA level $<1 \%$ and esterification-transesterification for FFA level $<5 \%$. The resulting yield for $1000 \mathrm{~kg}$ of raw material is $1051.75 \mathrm{~kg}$ CPO, $975.94 \mathrm{~kg} R P O$ and PFAD, $973.81 \mathrm{~kg}$ Refined Oil with Grand Inizio technology approach. The production cost model represents the total production cost influenced by the costs of Inside Battery Limit, Outside Battery Limit, general cost and glycerol valueadded.

\section{Keywords: Biodiesel, free fatty acid, modelling, palm oil, production cost}

\section{PENDAHULUAN}

Kebutuhan bahan bakar minyak nasional semakin meningkat seiring dengan peningkatan populasi dan pertumbuhan ekonomi di Indonesia. (Bangun, 2014). Peningkatan kebutuhan minyak nasional tidak sebanding dengan produksi sehingga pemerintah melakukan impor bahan bakar dari luar negeri. Solusi yang dibutuhkan dalam mengurangi proporsi bahan bakar adalah eksplorasi sumber energi terbarukan dengan mengandalkan sumber daya lokal. Salah satu sumber energi terbarukan yang berasal dari sumber daya lokal adalah biodiesel berbasis minyak sawit.

Biodiesel adalah bahan bakar alternatif pengganti solar yang bersumber dari minyak nabati dan hewani. Bahan bakar nabati ini terdiri dari fatty acid methyl ester (FAME) yang diperoleh melalui reaksi transesterifikasi antara minyak/lemak dengan metanol menggunakan katalis tertentu (Ivanoui et al., 2011; Taufiq-Yap et al., 2011).

Sumber daya lokal yang sangat potensial menjadi bahan baku biodiesel di Indonesia berasal dari minyak sawit. Sejak tahun 2006 Indonesia menjadi produsen minyak sawit terbesar dunia. Produksi minyak sawit di Indonesai akan semakin meningkat. Berdasarkan publikasi Oil World data minyak sawit Indonesia untuk periode 2013 sampai dengan September 2014 sebesar 30 juta ton, ekspor sebesar 20,9 juta ton dan penggunaan dalam negeri sebesar 9,10 juta ton (Oil World, 2014).

Peluang untuk mengembangkan biodiesel berbasis minyak sawit cukup besar terutama untuk substitusi solar. Saat ini penggunaan solar mencapai $40 \%$ dari total penggunaan bahan bakar minyak untuk sektor transportasi. Selain sektor transportasi penggunaan solar juga banyak digunakan pada sektor industri dan pembangkit listrik tenaga diesel (PLTD) (ESDM, 2013).

Kebutuhan biodiesel yang sangat prospektif menjadi perhatian pemerintah dengan menjamin pasar biodiesel. Jaminan pasar biodiesel dalam negeri dilakukan dengan mengeluarkan mandatori bahan bakar nasional (BBN) yang diatur dalam Permen ESDM no 25 tahun 2013 dan Permen ESDM no. 20 tahun 2014. Semenjak bulan September tahun 2013, sektor transportasi, industri, komersial dan pembangkit listrik diwajibkan memakai biodiesel minimal $10 \%$ dalam campuran solar dan akan terus meningkat menjadi $25 \%$ pada Januari 2025.

Pentingnya penggunaan biodiesel tidak sebanding dengan peningkatan produksi biodiesel di Indonesia. Banyak produsen biodiesel menghentikan produksinya dikarenakan harga jual yang tidak dapat menutupi biaya produksi (Aprobi, 2014).

Harga jual merupakan faktor penting agar biodiesel dapat bersaing dengan solar di dalam negeri. Langkah yang ideal dalam mengatasi permasalahan harga jual adalah mengetahui komponen pembentuk biaya produksi biodiesel dengan pendekatan produksi biodiesel. Pendekatan produksi biodiesel merupakan langkah awal yang dilakukan untuk mendapatkan proses transformasi dalam sistem yang kompleks karena melibatkan beberapa subsistem yang membentuk komponen biaya produksi (Purnomo, 2004).

Produksi biodiesel tergolong kepada industri proses karena kegiatan produksi biodiesel terkait dengan nilai tambah produk yang dihasilkan melalui pencampuran, pembentukan, dan atau perlakuan proses kimia (Haas, 2006). Kompleksitas produksi 
biodiesel berhubungan dengan bahan baku, suhu reaktor, aliran proses, alkohol, katalis, Asam Lemak Bebas (ALB), pemisahan, pemurnian dan daur ulang metanol (Marchetti et al., 2008).

Sistem pada produksi biodiesel merupakan sistem rantai pasok yang kompleks, melibatkan banyak aktor dan proses yang rumit. Wasson (2006) mengatakan bahwa suatu riset pemodelan sistem harus menentukan batasan (boundary) sistem untuk mempermudah pemahaman suatu sistem yang kompleks. Pemodelan produksi meliputi kajian pemodelan subsistem aliran proses transformasi bahan baku menjadi produk, pemodelan strategi dan kebijakan, pemodelan aliran informasi, dan pemodelan biaya produksi (Kumar dan Zander, 2007).

Fokus utama penelitian ini (boundary) adalah pemodelan biaya produksi pada aktor produsen biodiesel. Pemodelan produksi ini terdiri dari 3 aspek yang harus dikaji yaitu bahan baku, teknologi proses, dan biaya produksi.

Berdasarkan hal tersebut, tujuan penelitian ini adalah menentukan spesifikasi bahan baku biodiesel berbasis minyak sawit yang digunakan produsen di Indonesia, Kajian teknologi proses berdasarkan tipe bahan baku yang berbeda, dan pemodelan biaya produksi berdasarkan bahan baku dan teknologi proses produksi biodiesel berbasis minyak sawit.

\section{METODOLOGI PENELITIAN}

Kajian bahan baku biodiesel berbasis minyak sawit dilakukan dengan studi literatur dan survei lapangan. Tujuan kajian ini untuk mendapatkan jenis bahan baku dan spesifikasi yang digunakan oleh produsen biodiesel di Indonesia. Menurut Lee dan Ofori-Boateng (2013), keberlanjutan produksi biodiesel secara signifikan dipengaruhi oleh beberapa faktor, diantaranya yaitu sumber bahan baku, tipe bahan baku berdasarkan kandungan Asam Lemak Bebas (ALB), pengotor (impurities) dan kandungan trigliserida yang dikonversi menjadi biodiesel. Spesifikasi bahan baku akan menentukan teknologi proses yang digunakan.

Kajian teknologi proses dilakukan dengan survei lapangan, sedangkan perhitungan rendemen menggunakan pendekatan neraca massa provider teknologi pengolahan biodiesel Grand Inizio. Teknologi pengolahan Grand Inizio adalah teknologi proses biodiesel yang mampu memproses semua bahan baku biodiesel berdasarkan asam lemak bebas. Selain itu teknologi ini sangat proposional dalam proses scale-up sehingga mempermudah perhitungan neraca massa. Berdasarkan hal tersebut teknologi Grand Inizio dipilih sebagai acuan pada penelitian ini untuk mendapatkan model yang prosional dan representatif terhadap sistem nyata produksi biodiesel. Teknologi proses produksi biodiesel penting dikaji untuk mendapatkan tahapan proses dan neraca massa masingmasing unit operasinya. Masing-masing bahan baku ditentukan aliran proses berdasarkan kandungan ALB, jumlah bahan penolong dan utilitas yang digunakan.

Pemodelan biaya produksi dilakukan berdasarkan kajian bahan baku dan teknologi proses produksi biodiesel. Pendekatan pemodelan adalah teknik heurustik untuk mendapatkan model matematis biaya produksi biodiesel berbasis minyak sawit. Komponen biaya produksi terdiri dari biaya Inside Baterey Limited (ISB), Outside Baterey Limited (OSBL) dan, biaya umum (Carberry etal., 2007).

Perbedaan variasi bahan baku menyebabkan perbedaan tahapan proses dan aliran proses produksi sehingga terjadi perbedaan komponen biaya produksi terutama pada biaya ISBL dan OSBL (harga bahan baku, biaya utilitas, dan biaya bahan penolong). Struktur penyusun biaya produksi disusun berdasarkan kebutuhan biaya pendirian pabrik (Carberry et al., 2007, Towler dan Sinnot, 2008) yang telah disesuaikan dengan kebutuhan biaya proses produksi biodiesel berbahan baku minyak sawit.

Teknik heuristik merupakan suatu metode analisis berbasis pengalaman yang akan membantu penyelesaian sebuah masalah, proses belajar, dan penemuan. Teknik heuristik adalah metode yang menjelaskan tata cara berpikir untuk menghasilkan suatu keputusan (Eriyatno, 1998). Teknik heuristik merupakan pengembangan dari operasi aritmatika dan logika matematika dengan ciri-ciri adanya operasi aljabar, adanya perhitungan secara 
bertahap, mempunyai tahapan bertahap sehingga dapat dibuat algoritma komputer.

Tujuan penggunaan teknik heuristik adalah memudahkan para pengambil kebijakan agar proses pengambilan keputusan dapat dilakukan dengan cepat, menyelesaikan permasalahan dengan jalan penjaringan intisari permasalahan sehingga dibuat model matematikanya, serta menyelesaikan permasalahan yang bersifat sulit untuk dikuantifikasi.

Dalam metode heuristik, data dan informasi yang diperoleh dirumuskan dan direpresentasikan dengan metode yang dipilih sehingga dapat diperoleh solusi, walaupun solusi yang dicapai bukan yang optimal. Teknik ini banyak digunakan oleh beberapa peneliti seperti Paudel et al., (1998) untuk penentuan lahan sewa melalui mekanisme negosiasi, Viswanath (2000) pada perumusan kontrak pertanian di Palestina, Jackson (2003) dalam mengkaji restrukturisasi perusahaan melalui mekanisme kontribusi karyawan, Giannoccaro dan Pontrandolfo (2004) mengkaji teknik ini pada proses koordinasi rantai pasok, dan Yang (2011) yang telah membuat model risk sharing dalam sistem rantai pasok.

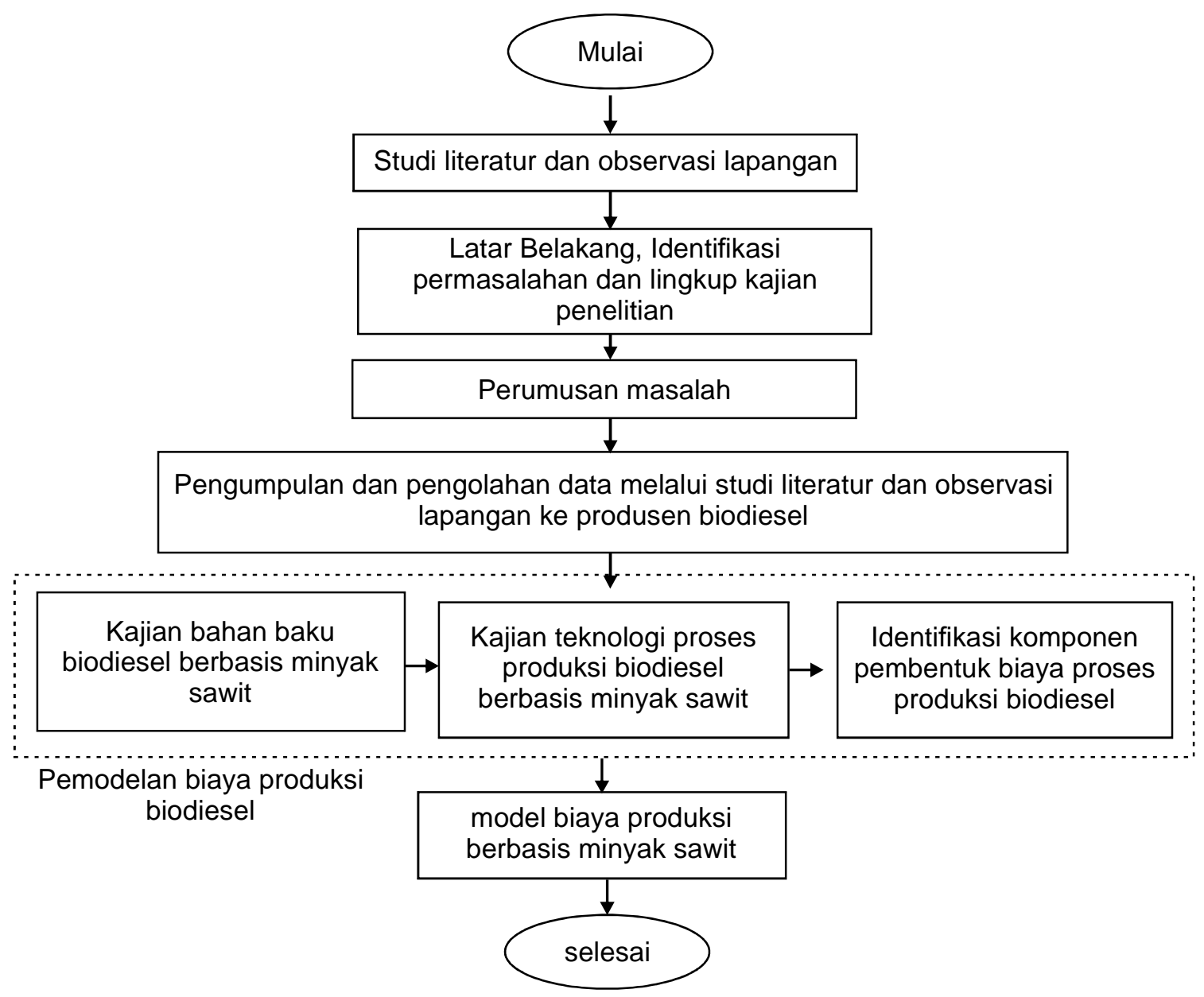

Gambar 1. Tahapan penelitian pemodelan produksi biodiesel berbasis minyak sawit

Tahapan penelitian ini secara sistematis ditampilkan pada gambar 1, Data dikumpulkan dalam penelitian ini berupa data primer dan sekunder. Data primer diperoleh melalui observasi langsung ke lapangan dan wawancara langsung dengan pakar yang sesuai dengan topik penelitian, alat bantu yang digunakan adalah kuesioner dan alat bantu rekam. Narasumber yang terlibat antara lain: produsen biodiesel (Direksi PT. Eterindo, Konsultan Biodiesel PTPN IV, kepala bagian bidang industri hilir kelapa 
sawit PT. Musim Mas, staff produksi biodiesel PT. Wilmar), pengusaha sawit (Komisaris PTPN V), Badan Pengkajian dan Penerapan Teknologi (BPPT) bagian biodiesel, Pusat Penelitian Kelapa Sawit (PPKS) bagian penelitian biodiesel, Kementerian ESDM (bagian bioenergi), sekretaris Asosiasi Produsen Biofuel Indonesia (Aprobi), Pertamina (bagian pemasaran). Data sekunder diperoleh dari kajian pustaka, laporan teknis dari dinas terkait, lembaga penelitian. Pakar yang terlibat berasal dari kalangan peneliti akademisi dan praktisi serta pengusaha biodiesel. Pemilihan lokasi dan pakar dilakukan secara purposive. Lokasi pengumpulan data dilakukan pada PT MusimMas, PT Wilmar, PT Eterindo Wahanatama Tbk. dan PTPN IV.

Penelitian ini dilakukan dengan menggunakan model matematis. Analisis data pada penelitian ini dilakukan secara kuantitatif dengan pendekatan heurisitik dengan memperhitungkan variabel-variabel pembentuk sub model dalam model produksi biodiesel, berupa bahan baku, teknologi proses dan biaya produksi.

\section{HASIL DAN PEMBAHASAN}

\section{Biodiesel Berbasis Minyak Sawit}

Biodiesel berbasis minyak sawit merupakan salah satu sumber energi terbarukan yang bersumber dari minyak sawit. Peningkatan penggunaan biodiesel dikarenakan peningkatan impor bahan bakar dari luar negeri sehingga biodiesel digunakan sebagai bahan bakar pengganti (substitusi) solar. Penggunaan minyak sawit sebagai sumber biodiesel oleh Pertamina pada awalnya dimulai dengan pencampuran $1 \%$ dengan solar, produk pencampuran biodiesel dengan solar yang dihasilkan Pertamina dikenal dengan sebutan biosolar. Peningkatan konsumsi produk biosolar semakin meningkatkan pemanfaatan biodiesel seiring dengan peraturan pemerintah mengenai mandat penggunaan bahan bakar nabati (BBN) melalui Peraturan Kementerian (Permen) ESDM No 30 Tahun 2008, Permen ESDM No 25 Tahun 2013 dan Permen ESDM No 20 Tahun 2014. Kebutuhan dan produksi minyak sawit akan semakin meningkat dari tahun ke tahun (Gambar 2).

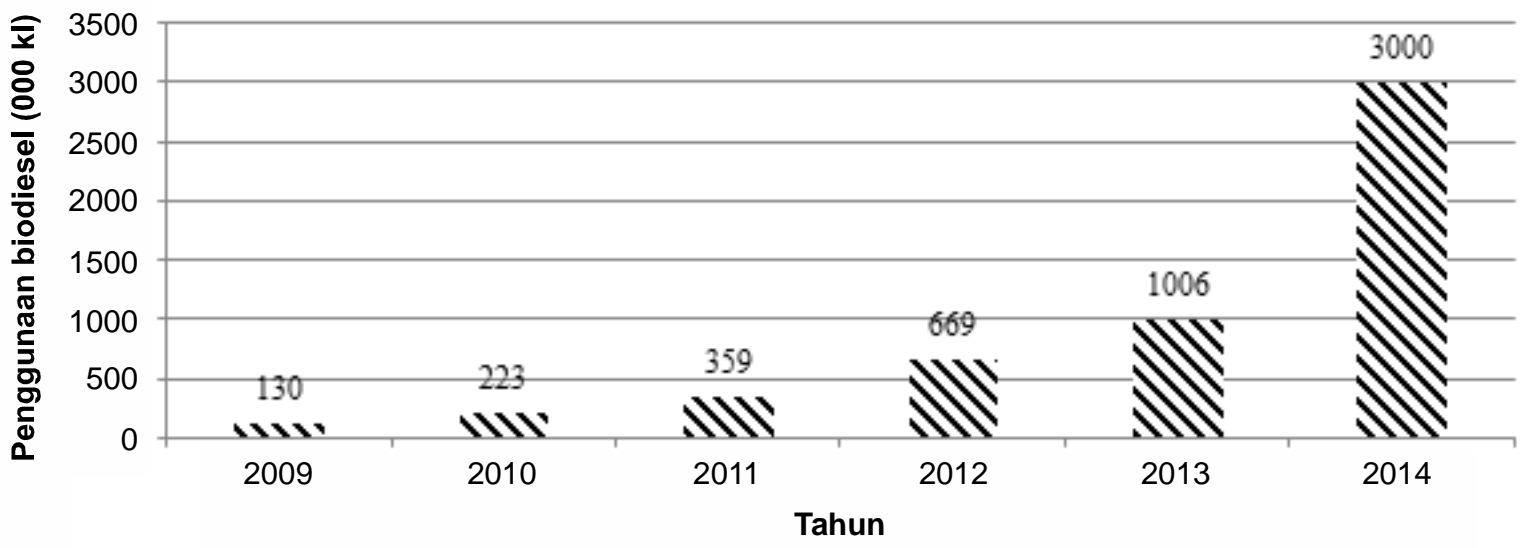

Gambar 2. Perkembangan penggunaan biodesel oleh pertamina tahun 2009-2014 Sumber : Bangun, 2014

Biodiesel mempunyai sifat kimia dan fisika yang serupa dengan solar sehingga dapat digunakan langsung untuk mesin diesel atau dicampur dengan solar. Walaupun kandungan kalori biodiesel serupa dengan solar, tetapi karena biodiesel mengandung oksigen, maka flash pointnya lebih tinggi sehingga tidak mudah terbakar (Lee dan Ofori-Boateng, 2013). Biodiesel tidak mengandung sulfur dan senyawa benzena yang memiliki sifat karsinogenik, sehingga biodiesel merupakan bahan bakar yang bersih dan lebih mudah ditangani bila dibandingkan dengan solar (Ahmad et al., 2013). Perbedaan antara biodiesel dengan solar terutama adalah pada komposisinya. Perbandingan kualitas biodiesel minyak sawit dengan solar dapat dilihat pada Tabel 1. 
Tabel 1 Perbandingan antara biodiesel minyak sawit dan solar

\begin{tabular}{lrr}
\hline $\begin{array}{l}\text { Karakteristik } \\
\text { Sumber }\end{array}$ & $\begin{array}{c}\text { Palm Biodiesel } \\
\text { Renewable }\end{array}$ & $\begin{array}{c}\text { Petroleum Diesel } \\
\text { Fosil }\end{array}$ \\
\hline Nilai Kalori $(\mathrm{MJ} / \mathrm{kg})$ & 41.3 & 46.8 \\
Panas Pembakaran $(\mathrm{kJ} / \mathrm{kg})$ & 40.135 & 45.8 \\
Angka Setana & 65 & 53 \\
Titik Nyala $\left({ }^{\circ} \mathrm{C}\right)$ & 174.0 & 98.0 \\
Pour Point $\left({ }^{\circ} \mathrm{C}\right)$ & 16.0 & 15.0 \\
Titik Kabut $\left({ }^{\circ} \mathrm{C}\right)$ & 16.0 & 18.0 \\
Densitas pada suhu $40^{\circ} \mathrm{C}(\mathrm{kg} / \mathrm{L})$ & 0.855 & 0.823 \\
Viskositas pada suhu $40^{\circ} \mathrm{C}(\mathrm{CST})$ & 4.5 & 4.0 \\
Kandungan Sulfur $(\%$ wt) & 0.04 & 0.10 \\
Karbon Residu (\% wt) & 0.02 & 0.14 \\
\hline
\end{tabular}

Sumber: Nagi et al. (2008)

\section{Identifikasi Bahan Baku}

Proses identifikasi dalam penelitian ini digunakan untuk mendapatkan informasi antara lain: mengenai bahan baku yang digunakan oleh produsen biodiesel, spesifikasi bahan baku biodiesel berbasis minyak sawit. Proses identifikasi dilakukan dengan survei pakar dan pengamatan pada beberapa produsen biodiesel. Survei pakar dilakukan pada Balai Pengkajian Penerapan Teknologi (BPPT) dan Pusat Penelitian Kelapa Sawit (PPKS). Pengamatan dilakukan pada produsen biodiesel di
Indonesia yaitu PT Wilmar, PT Eterindo dan PT Musimas, dan PTPN IV. Berdasarkan pengamatan diperoleh hasil bahwa bahan baku yang digunakan adalah Crude Palm Oil (CPO), Refined Palm Oil (RPO), Refined Bleached Deodorized Palm Oil (RBDPO), Refined Bleached Deodorized Palm Olein (RBD olein), Refined Bleached Deodorized Palm Stearin (RBD stearin) dan Palm Fatty Acid Distillate (PFAD). Karakteristik masingmasing bahan baku yang digunakan berdasarkan pengamatan dan hasil survey dapat dilihat pada Tabel 2.

Tabel 2 Karakteristik bahan baku biodiesel

\begin{tabular}{lccl}
\hline Bahan Baku & Kandungan FFA $(\%)$ & Pengotor & \multicolumn{1}{c}{ Perusahaan } \\
\hline CPO & Max. 5 & $0.050 \pm 0.006$ & PTPN IV \\
RPO & $3-5$ & - & PT. Wilmar \\
RBDPO & Max. 0.05 & - & PT. Musim Mas \\
RBD Olein & Max. 0.05 & - & PT. Musim Mas, PT. Eterindo, PT. Wilmar \\
RBD Stearin & Max. 0.05 & - & PT. Musim Mas, PT. Eterindo, PT. Wilmar \\
PFAD & $74.6-93.9$ & - & PT. Musim Mas, PT. Eterindo, PT. Wilma \\
\hline
\end{tabular}

CPO merupakan bahan baku biodiesel mengandung asam lemak yang terikat secara alami dalam struktur sejenis ester yang disebut trigliserida. Selain itu CPO juga mengandung pengotor yang berasal dari komponen lain yang umumnya harus dibuang selama proses pemurnian. Keberadaan komponen yang membentuk gum dan pengotor lainnya harus dibuang dalam tahap persiapan bahan baku pada proses produksi biodiesel.

RPO atau biasa disebut sebagai Degummed Bleached Palm Oil (DBPO), merupakan minyak yang diperoleh dari ekstraksi daging kelapa sawit dan telah melalui proses penghilangan gum (degumming) dan penghilangan warna (bleaching) sehingga memiliki kandungan lilin dan pengotor yang rendah namun kandungan ALB nya masih tinggi (Morad et al., 2006; Idoko et al., 2013).

RBDPO merupakan hasil dari pemurnian CPO, yaitu ekstrak dari bagian mesokarp buah kelapa sawit. Proses pemurnian CPO menghasilkan RBDPO meliputi tahapan degumming, netralisasi 
(deasidifikasi), bleaching, dan penghilangan bau (deodorizing) (Winarno, 2008). Kesemua tahapan ini disebut refined bleached deodorized (RBD), bahan baku biodiesel diperlukan hanya pada tahapan pemisahan gum dan penghilangan asam/netralisasi. Proses pengolahan RBDPO selanjutnya akan menghasilkan RBDP olein dan RBDP stearin yang merupakan hasil fraksinasi dan kristalisasi RBDPO hingga diperoleh produk padat berupa stearin dan produk cair berupa olein.

RBDP olein merupakan fraksi cair yang diperoleh melalui proses fraksinasi RBDPO (WFP, 2011; EAS, 2013). RBD olein banyak digunakan sebagai minyak goreng dan juga persiapan makanan komersial. RBD olein terdiri dari beberapa asam lemak, komponen terbesar asam lemak penyusun RBD olein adalah asam palmitat dan asam oleat.
RBDP stearin merupakan fraksi dengan titik leleh yang tinggi yang diperoleh dari proses fraksinasi RBDPO (EAS, 2013). Komponen lemak yang terbesar penyusun RBD stearin adalah asam palmitat dan asam oleat.

PFAD adalah produk turunan hasil samping pada proses deodorisasi minyak kelapa sawit dengan kandungan ALB yang tinggi (Ira et al., 2013). Menurut Igor et al., (2011) kandungan ALB ada PFAD sekitar 93\%. PFAD berwarna kuning cerah dan berbentuk padat pada temperatur ruang (Chongkhong et al., 2009). Komposisi PFAD dapat bervariasi tergantung dari beberapa faktor, diantaranya yaitu bahan baku dan kondisi proses pemurnian minyak (Gunawan et al., 2008). Karakteristik masing-masing bahan baku dapat dapat diihat pada Tabel 3. PFAD banyak dipertimbangkan karena harganya yang relatif murah.

Tabel 3 Karakteristik CPO, RPO, RBDPO, RBD olein, RBD stearin dan PFAD

\begin{tabular}{|c|c|c|c|c|c|c|c|}
\hline \multirow[t]{2}{*}{ Karakteristis } & \multirow[t]{2}{*}{ Satuan } & CPO & RPO & RBDPO & RBD Olein & $\begin{array}{c}\text { RBD } \\
\text { Stearin }\end{array}$ & PFAD \\
\hline & & $\begin{array}{l}\text { Hayyan et } \\
\text { al. (2013) }\end{array}$ & $\begin{array}{l}\text { Idoko et al. } \\
\text { (2013) }\end{array}$ & $\begin{array}{l}\text { Elburg } \\
\text { Global } \\
(2009) \\
\end{array}$ & EAS (2013) & EAS (2013) & $\begin{array}{l}\text { Moh et al. } \\
\text { (1999) }\end{array}$ \\
\hline $\begin{array}{l}\text { Asam lemak } \\
\text { dominan }\end{array}$ & - & $\begin{array}{r}\text { Asam } \\
\text { Palmitat } \\
\end{array}$ & $\begin{array}{r}\text { Asam } \\
\text { Palmitat } \\
\end{array}$ & $\begin{array}{r}\text { Asam } \\
\text { Palmitat }\end{array}$ & $\begin{array}{r}\text { Asam } \\
\text { Palmitat } \\
\end{array}$ & Asam Oleat & $\begin{array}{r}\text { Asam } \\
\text { Palmitat }\end{array}$ \\
\hline FFA & $(\%)$ & $7 \pm 0.30$ & $3-5$ & Max. 0.05 & Max. 0.3 & $\operatorname{Max} 0.25$ & $74.6-93.9$ \\
\hline $\begin{array}{l}\text { Bilangan } \\
\text { asam }\end{array}$ & $(\mathrm{mg} \mathrm{KOH} / \mathrm{g})$ & & $24.19 \pm 0.12$ & - & & - & $196-222$ \\
\hline $\begin{array}{l}\text { Bilangan } \\
\text { peroksida }\end{array}$ & $\begin{array}{c}\text { (meq } \\
02 / \mathrm{Kg})\end{array}$ & $7.5 \pm 0.65$ & $32.10 \pm 0.05$ & Max. 0.05 & Max. 10 & $\operatorname{Max} 10$ & - \\
\hline Bilangan iod & $(\mathrm{g} \mathrm{I} / 2 / 100 \mathrm{~g})$ & - & $45.81 \pm 2.18$ & $48-56$ & $56-62$ & $21-48$ & $50.3-62.7$ \\
\hline $\begin{array}{l}\text { Bilangan } \\
\text { penyabunan }\end{array}$ & $(\mathrm{mg} \mathrm{KOH} / \mathrm{g})$ & $198 \pm 1.70$ & $155.67 \pm 0.09$ & - & $190-205$ & $193-205$ & 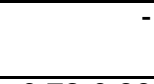 \\
\hline $\begin{array}{l}\text { Massa jenis } \\
\text { pada } 50^{\circ} \mathrm{C}\end{array}$ & $(\mathrm{kg} / \mathrm{L})$ & - & - & - & & - & $0.72-0.89$ \\
\hline $\begin{array}{l}\text { Komponen } \\
\text { tak } \\
\text { tersabunkan }\end{array}$ & (\%) & - & $7.58 \pm 0.07$ & - & & - & $0.9-4.5$ \\
\hline Titik leleh & $\left({ }^{\circ} \mathrm{C}\right)$ & - & - & $36-40$ & & - & - \\
\hline Kadar air & $(\%)$ & $1.03 \pm 0.1$ & 0,2 & Max. 0.05 & $\operatorname{Max} 0.1$ & $\operatorname{Max} 0.15$ & - \\
\hline Impurities & $(\%)$ & $0.05 \pm 0.006$ & - & - & $\operatorname{Max} 0.1$ & $\operatorname{Max} 0.15$ & - \\
\hline
\end{tabular}

\section{Teknologi Proses Biodiesel}

Teknologi yang umumnya digunakan secara komersial dalam memproduksi biodiesel adalah esterifikasi dan atau transesterifikasi dari minyak dengan alkohol (metanol) dan bantuan katalis untuk menghasilkan biodiesel (fatty acid methyl eter-FAME) sebagai produk utama dan gliserol sebagai produk samping (Meher, 2006; Rahayu, 2009; Paryanto, 2013).

Penentuan teknologi proses didasarkan pada kandungan ALB, pengotor dan trigliserida. Jenis bahan baku tertentu, selain mengandung bahan ALB yang tinggi terdapat pengotor dan sisa (residu) yang dapat menghambat proses produksi biodiesel, sehingga beberapa perlakuan 
pendahuluan diperlukan seperti pembersihan serta proses penghilangan gum. Varian teknologi proses pengolahan biodiesel berdasarkan bahan baku terdapat pada Gambar 3.

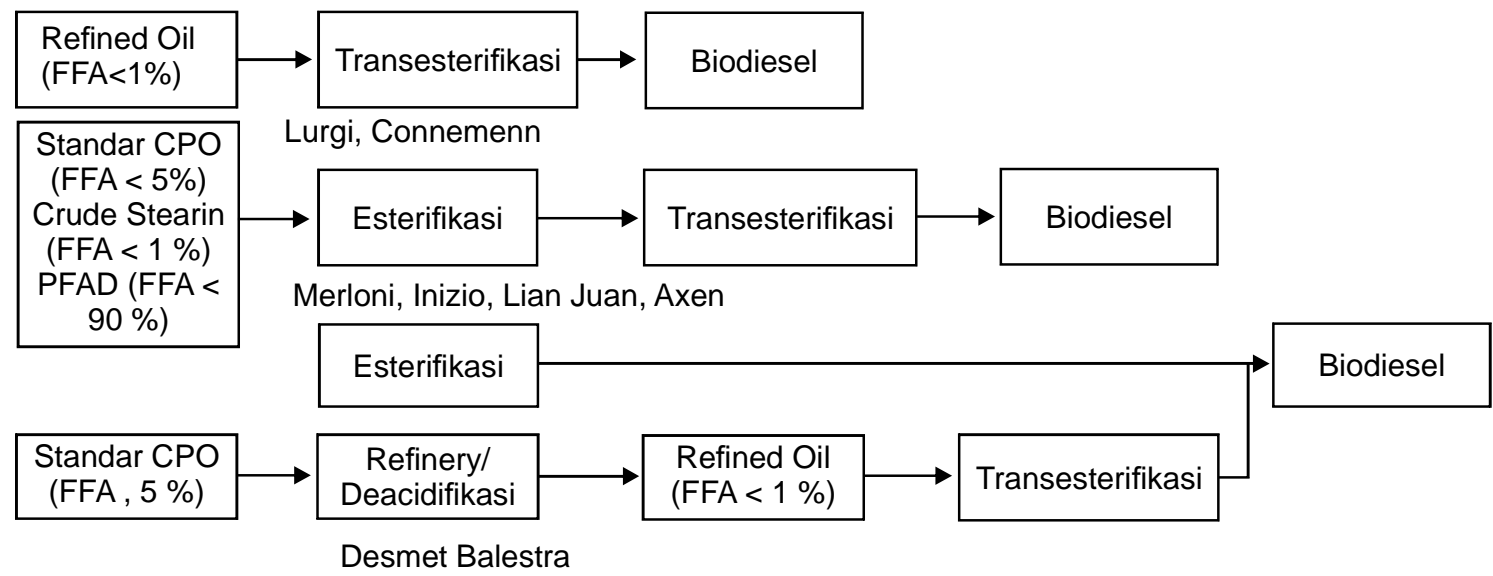

Gambar 3. Varian teknologi pengolahan biodiesel berdasarkan bahan baku

Secara garis besar ketiga varian pada Gambar 3, selalu terdiri dari 3 kumpulan unit operasi kimia yaitu: unit proses persiapan bahan baku meliputi pembersihan bahan baku (physical refining), unit reaksi kimia pembentukan FAME, unit pemurnian produk (Meher, 2006; Melero, 2014).

\section{Pretreatment, Bleaching dan Degumming}

Tahapan pertama dalam proses produksi adalah pembersihan bahan baku (pretreatment), yaitu pembersihan bahan baku dari kotoran ataupun kandungan air, serta tahapan penghilangan gum (degumming) yang disebabkan karena adanya enzim yang masih aktif dari bahan baku. Perlakuan pendahuluan dan penghilangan gum bertujuan untuk menghilangkan kotoran yang dapat mempengaruhi stabilitas produk minyak pada akhir proses produksi biodiesel. Tujuan penghilangan gum adalah untuk menghilangkan phospolipid CPO yang dapat mengganggu stabilitas produk akhir. Secara konvensional penghilangan gum adalah pembentukan flok-flok dari zat-zat yang bersifat koloidal dalam minyak mentah (Syafri et al., 2010). Cara yang sering dilakukan adalah menambahkan H3PO4, H2SO4, atau $\mathrm{HCl}$. Penambahan senyawa asam ini dapat menggumpalkan dan mengendapkan zat-zat seperti protein, fosfatida, dan resin yang terdapat dalam minyak mentah. Prinsip penghilangan gum dengan kaustik alkali adalah partikel-partikel sabun yang terbentuk akan menyerap zat-zat lendir dan sebagian pigmen.

\section{Esterifikasi}

Esterifikasi merupakan tahap konversi minyak/lemak menjadi metil ester dari asam lemak menggunakan katalis asam dan mencampurkan dengan alkohol/metanol. Tantangan utama dalam memproduksi biodiesel dari bahan baku dengan kualitas rendah adalah perlakuan terhadap ALB. Keberadaan ALB akan sangat mengganggu dan menghambat proses transesterifikasi karena akan membentuk sabun, mengurangi hasil produk dan meningkatkan kesulitan dalam pemisahan produk (Verhe et al., 2011; Lee et al., 2013). Proses yang dapat dilakukan adalah dengan menambahkan katalis tetapi berupa soda caustic untuk memisahkan ALB dengan membentuk sabun dengan bahan alkali, proses yang sering digunakan oleh industri/produsen biodiesel adalah penggabungan antara esterifikasi dengan katalis asam untuk menurunkan kadar ALB kemudian diikuti dengan transesterifikasi dengan katalis basa (Mahlia et al., 2012).

\section{Transesterifikasi}

Transesterifikasi merupakan tahap konversi minyak/lemak menjadi metil ester dari asam lemak struktur trigliserida dengan mencampurkan minyak/lemak dengan alcohol / metanol menggunakan katalis basa 
(Ivanoui et al. 2011; Ahmad et al. 2013). Selain biodiesel, reaksi transesterifikasi menghasilkan hasil samping berupa gliserol (Lee dan Ofori-Boateng 2013). Reaksi transesterifikasi hanya dapat berjalan dengan baik apabila bahan baku yang digunakan mempunyai kandungan ALB yang rendah atau telah melalui tahapan proses esterifikasi untuk menurunkan kadar ALB.

\section{Drying, Filtering dan Dry Washing}

Drying, filtering dan dry washing merupakan pemurnian biodiesel yang dilakukan untuk menghilangkan komponenkomponen yang tidak diinginkan pada biodiesel yang dihasilkan dari proses transesterifikasi. Proses dry washing dilakukan untuk menghilangkan gliserol, katalis, air, busa, dan garam yang terbawa dari proses transesterifikasi. Dry washing dapat dilakukan dengan udara, ion exchange, partikel resin dan magnesol. Filtering dilakukan untuk menghilangkan partikel-partikel berukuran kecil yang terkandung dalam biodiesel hasil selama proses pendahuluan, penghilangan gum, dan pemucatan pada reaksi esterifikasi dan transesterifikasi. Tahapan pengeringan (drying) dilakukan untuk menguapkan air dari biodiesel, biodiesel akan berwarna kuning kemerahan yang mengindikasikan adanya air yang terkandung pada biodiesel. Metode ini dapat menggunakan destillasi atau settling (Berrios dan Skelton, 2008). Hasil yang diharapkan dari proses ini adalah biodiesel dengan tingkat kemurnian $99 \%$.

\section{Teknologi Grand Inizio}

Teknologi Grand Inizio mampu mengolah berbagai jenis bahan baku tersebut dalam satu proses produksi. Proses produksi yang diterapkan pada teknologi Grand Inizio mempunyai karakteristik produksi kontinyu. Katalis yang digunakan antara lain; katalis asam paratoluene sulfonat (PTSA), katalis basa caustic soda $(\mathrm{NaOH})$. Penggunaan katalis PTSA mempunyai keunggulan pada rendahnya konsentrasi sulfur pada produk biodiesel, dibandingkan dengan katalis asam sulfur meskipun reaksi yang dihasilkan lebih cepat (BUMN PT X ; Verhe et al., 2011). Proses destilasi atau pemisahan menggunakan bahan tambahan silica, sedangkan proses penyaringan (filtering) menggunakan bahan eco-sponge untuk menjernihkan produk. Diagram alir dan neraca massa untuk semua bahan baku diperlihatkan pada gambar 4 .

\section{Pemodelan Biaya Produksi Biodiesel}

Berdasarkan kajian pada bahan baku dan teknologi proses, disusun model biaya produksi biodiesel berdasarkan submodel bahan baku, teknologi proses, biaya produksi untuk menghasilkan model biaya produksi biodiesel berbasis minyak sawit. Model biaya produksi dikembangkan menggunakan teknik heuristik mengacu kepada (Carberry et al., 2007).

\section{Submodel Bahan Baku}

Beberapa alasan pemakaian bahan baku biodiesel oleh produsen adalah teknologi peralatan, ketersediaan bahan baku, harga bahan baku dan standar kualitas yang diminta oleh konsumen. Minyak sawit adalah produk yang memiliki harga yang fluktuatif, dipengaruhi oleh harga bahan baku, dan nilai tukar rupiah terhadap dollar. Harga bahan baku total dipengaruhi oleh harga minyak sawit, harga minyak mentah (crude oil), permintaan dan nilai tukar rupiah:

$$
\begin{array}{ll}
T_{\text {Grandlnizio }} & =f\left(R, C A_{\text {PTSA,Methanol,B.Earth,Caustic Soda }}\right. \\
& \left.M_{\text {Grandlnizio }}, Y_{\text {Grandlnizio }}\right) \\
T_{\text {Grandlnizio }} & : \text { Teknologi Grand Inizio } \\
\mathrm{R} & \text { :Jenis bahan baku (ALB, } \\
& \text { Pengotor) } \\
\mathrm{CA} & \text { :Katalis dan bahan penolong } \\
\mathrm{M}_{\text {Grandlnizio }} & : \text { Mesin proses Grand Inizio } \\
\mathrm{Y}_{\text {Grandlnizio }} & \text { :Rendemen teknologi Grand } \\
& \text { Inizio }
\end{array}
$$

\section{Sub Model Biaya Produksi}

Komponen biaya produksi didefinisikan berdasarkan diagram alir produksi biodiesel menggunakan Teknologi Grand Inizio pada gambar 4. Komponen biaya produksi diidentifikasi dari teknologi proses produksi biodiesel sebelumnya. Komponen biaya produksi terdiri dari biaya ISBL, OSBL dan biaya umum. Biaya ISBL adalah biaya yang dihasilkan dari proses utama konversi bahan 
baku menjadi produk, sedangkan OSBL adalah biaya yang dihasilkan dari kegiatan pendukung proses utama.

$$
\begin{aligned}
& \mathrm{TBP}_{\mathrm{i}}=\mathrm{BP}_{\mathrm{i}}(\mathrm{ISBL})+\mathrm{BMFP}_{\mathrm{i}}(\mathrm{OSBL})+\mathrm{BU}- \\
& \mathrm{H}_{\text {(gliserol) }}
\end{aligned}
$$

Perhitungan biaya produksi lingkup ISBL menggunakan teknik heurisitik dirumuskan sebagai berikut:

$$
\begin{aligned}
& \mathrm{Bp}_{\mathrm{i}}(\mathrm{ISBL})=\left\{\left(\mathrm{F}_{\mathrm{i}} \times \mathrm{PF}_{\mathrm{i}}\right)+\left(\mathrm{Me}_{\mathrm{i}} \times \mathrm{PMe}\right)+\left(\mathrm{Cta}_{\mathrm{i}} \mathrm{x} \quad \mathrm{Pch}_{\mathrm{i}}\right.\right. \\
& \left.P C t a_{i}\right)+\left(\text { Ctb } x \text { PCtb }_{i}\right)+\left(C_{i} x\right.
\end{aligned}
$$

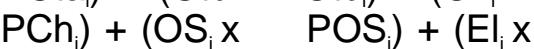

$$
\begin{aligned}
& \text { PUI) }\} / y_{i}
\end{aligned}
$$

dimana

$\mathrm{Bp}_{\mathrm{i}}(\mathrm{ISBL})$

$\mathrm{Pf}_{\mathrm{i}}$

Pme

Pcta $_{i}$

Pctb $_{i}$
: Biaya produksi FAME per satuan massa FAME untuk jenis bahan Baku ke-i

: Harga bahan baku jenis- I

: Harga methanol per satuan massa

: Harga katalis asam untuk bahan bakuke-i

: Harga katalis basa untuk bahan bakuke-i

: Harga kimia untuk bahan baku ke-i

: Harga bahan penolong lain untuk bahan baku ke-i

: Harga utiliatas

: yield untuk bahan baku I

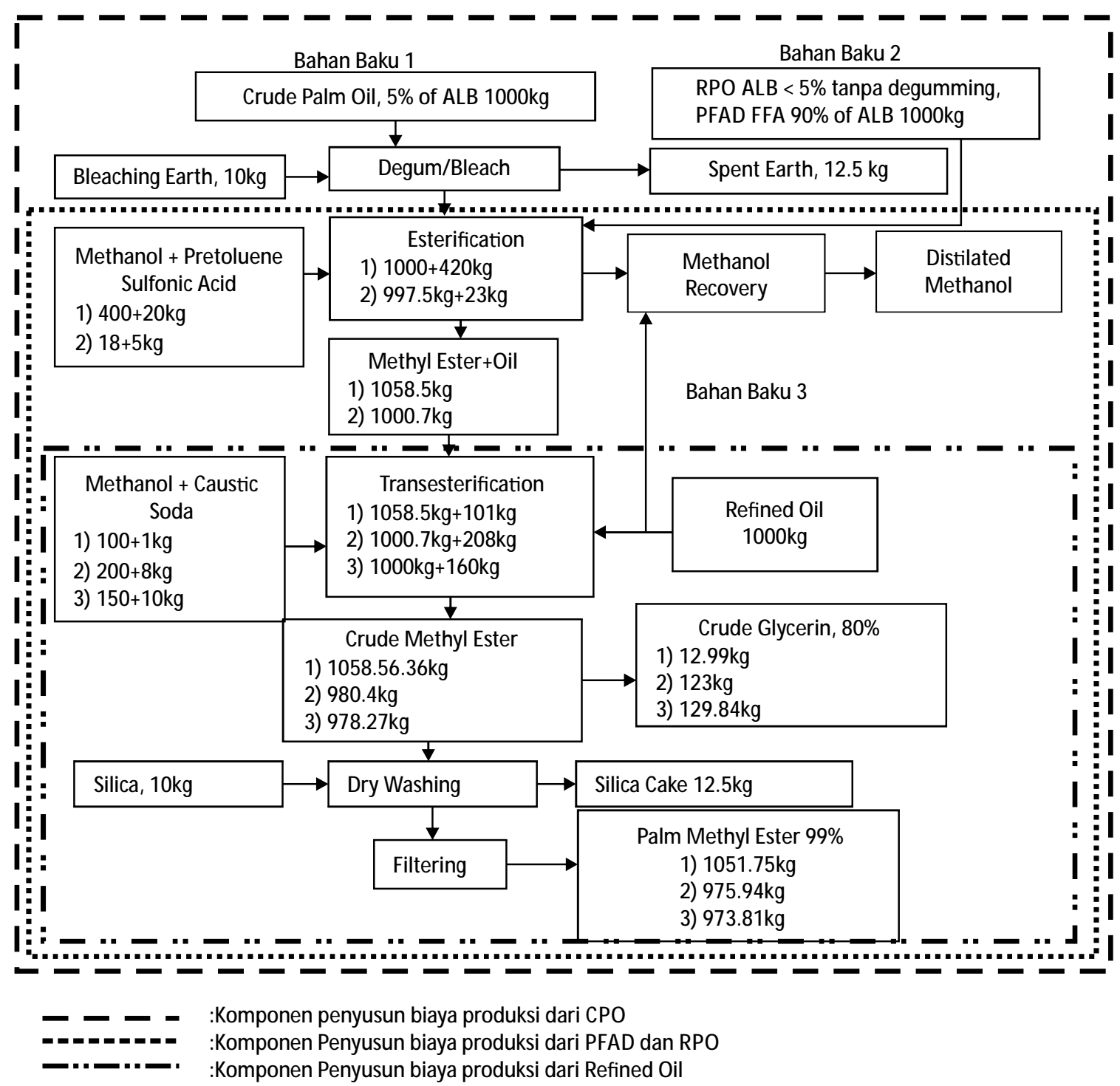

Gambar 4. Neraca massa dan komponen pembentuk biaya proses produksi biodiesel dengan teknologi Grand Inizio 
Tambahan biaya perawatan produk dan bahan baku (produk and feedstock handling) dalam OSBL

BMFP $_{i}($ OSBL $)=F_{i}\left(E_{1 m f} \times P E I+\operatorname{Stmf}_{i} x\right.$ $P S t)+B D_{i}(E I m B D \times P E I+S t m B D \times P s t)$

\begin{tabular}{|c|c|}
\hline BMFP $_{\mathrm{i}}$ & $\begin{array}{l}\text { Biaya perawatan bahan } \\
\text { baku-idan produk. }\end{array}$ \\
\hline$F_{i}$ & bahan baku-lp \\
\hline PEI & Harga listrik \\
\hline Pst & Harga uap \\
\hline Elmf $_{i}$ & $\begin{array}{l}\text { Penggunaan listrik untuk } \\
\text { perawatan per satuan } \\
\text { bahan baku ke-i }\end{array}$ \\
\hline $\operatorname{Stmf}_{i}$ & $\begin{array}{l}\text { Penggunaan steam untuk } \\
\text { perawatan persatuan } \\
\text { bahan baku ke-i }\end{array}$ \\
\hline
\end{tabular}

$\begin{array}{ll}\text { ElmBD } & \begin{array}{l}\text { Penggunaan listrik untuk } \\ \text { perawatan biodiesel }\end{array} \\ \text { StmBD } & \begin{array}{l}\text { Penggunaan steam untuk } \\ \text { perawatan biodiesel. }\end{array}\end{array}$
$\mathrm{BU}=\mathrm{TK}+\mathrm{ADM}+\mathrm{PER}+\mathrm{INS}+\mathrm{DEP}+$ $\mathrm{PEM}+\mathrm{TAX}$

dimana

$\begin{array}{ll}\text { BU } & : \text { Biaya umum } \\ \text { TK } & : \text { Biaya tenaga kerja } \\ \text { ADM } & : \text { Administrasi umum } \\ \text { PER } & : \text { Biaya perawatan mesin } \\ \text { INS } & : \text { Asuransi } \\ \text { DEP } & : \text { Depresiasi } \\ \text { PEM } & : \text { Pemasaran dan distribusi } \\ \text { TAX } & : \text { Pajak }\end{array}$

Berdasarkan rumusan diatas, maka disusun komponen penyusun biaya produksi yang dapat dilihat pada Tabel 4.

Tabel 4. Struktur penyusun biaya produksi biodiesel

\begin{tabular}{|c|c|c|}
\hline Komponen Biaya Produksi & Jenis biaya & Perhitungan \\
\hline $\begin{array}{l}\text { - } \text { OSBL } \\
\text { - } \text { ISBL } \\
\text { - } \text { Perawatan } \\
\text { - } \text { Asuransi } \\
\text { - } \text { Admaga Kerja } \\
\text { - } \text { Depresiasi } \\
\text { - Pemasaran dan distribusi } \\
\text { - Pajak }\end{array}$ & $\begin{array}{ll}\text { - } & \text { Biaya perawatan bahan baku } \\
& \text { dan produk. } \\
\text { - } & \text { Biaya bahan baku. } \\
\text { - } & \text { Biaya Utilitas. } \\
\text { - } & \text { Biaya bahan penolong } \\
\text { - } & \text { Biaya perawatan mesin } \\
\text { - } & \text { Biaya asuransi } \\
& \text { Biaya tenaga kerja }\end{array}$ & $\begin{array}{l}\text { - } 15 \% \text { dari biaya perawatan } \\
\text { - } \quad \text { Berdasarkan harga pasar } \\
\text { minyak sawit. } \\
\text { - } \text { Berdasarkan harga utilitas yag } \\
\text { digunakan } \\
\text { - } \quad \text { Berdasarkan harga pasar } \\
\text { - } \quad 1 \% \text { dari biaya investasi mesin. } \\
\text { - Jumlahnya berdasarkan biaya investasi. } \\
\text { - dan peralatan serta UMR. } \\
\text { - } 20 \% \text { dari tenaga kerja operasi. } \\
\text { - } 2 \% \text { dari biaya investasi mesin. } \\
\text { - } 2 \% \text { dari total biaya produksi. } \\
\text { - } 2 \% \text { dal biaya investasi }\end{array}$ \\
\hline
\end{tabular}

Sumber: Carberry et al., (2007)

\section{KESIMPULAN DANSARAN}

\section{Kesimpulan}

Hasil identifikasi bahan baku biodiesel berbasis minyak sawit yang digunakan oleh produsen biodiesel adalan CPO, RPO, RBDPO, RBD Olein, RBD Stearin, dan PFAD. Komponen yang penting diperhatikan pada bahan baku adalah kadar lemak bebas (FFA), pengotor (impurities) dan kadar trigliserida yang akan dikonversi menjadi biodiesel. Teknologi proses produksi biodiesel ditentukan berdasarkan kadar pengotor dan FFA dari bahan baku. Bahan yang mengandung FFA dan pengotor sangat tinggi perlu dilakukan perlakuan pretreatment, bleaching, degumming, dan estrifikasi, proses ini dinamakan esterifikasitransesterifikasi. Bahan yang mengandung FFA dan pengotor sangat sedikit dapat langsung dilakukan proses transesterifikasi. Teknologi Grand Inizio merupakan teknologi provider yang dapat mengolah bahan baku berdasarkan kadar FFA. Berdasarkan teknologi dan spesifikasi bahan baku model 
biaya produksi biodiesel dipengaruhi oleh komponen ISBL, OSBL, biaya umum dan nilai tambah hasil samping yaitu gliserol.

\section{Saran}

Perlu adanya perbandingan teknologi proses lain untuk dijadikan referensi dalam menyusun komponen biaya produksi, serta perlu pengkajian rantai pasok, strategi dan kebijakan pendukung harga jual biodiesel.

\section{UCAPAN TERIMA KASIH}

Terima kasih penulis ucapkan kepada Prof. Dr. Ir. Sukardi MM, Prof. Dr. Ir. Ani Suryani DEA, Prof. Dr. Ir. Muhammad Romli MSc.St selaku pembimbing.

\section{DAFTAR PUSTAKA}

Ahmad, M., Khan, M. A., Zafar, M., Sultana, S. 2013. Practical handbook on biodiesel production and properties. Boca Raton (US): CRC Press.

Aprobi. 2014. Kemampuan penyediaan biodiesel dalam mendukung mandatori biodiesel dan masalahnya. [Seminar Nasional Kebijakan Mandatory Biodiesel] Bogor (ID): PASPI.

Bangun, D. 2014. Important role of palm oil in food security: food and regulation. Disampaikan pada International Oil Palm Conference, 17-19 Juni 2014. Dewan Minyak Sawit Indonesia.

Berrios, M., Skelton, R. L. 2008. Comparison of purification methods for biodiesel. Chemical Engineering Journal. 144: 459-465.

Carberry, E. 2007. Plant design and economics for chemical engineers. Colorado (US): McGraw Hill.

Chongkhong, S., Tongurai, C., Chetpattananondh, P., Bunyakan, C. 2009. Continuous esterification for biodiesel production from palm fatty acid distillate using economical process. Renewable Energy. 34 (4): 1059-1063.
[EAS] East African Standard. 2013. Draft East African Standard: Palm Olein Spesification [Internet]. diunduh 2014.

[ESDM] Kementerian Energi dan Sumberdaya Mineral. 2013. Informasi teknis biodiesel. Jakarta (ID): Kementerian Energi dan Sumberdaya Mineral.

Eriyatno. 1998. IImu Sistem: Meningkatkan mutu dan efektifitas manajemen. Bogor (ID): IPB Press.

Elburg Global. 2009. Technical spesifications of RBD palm oil [Internet]. [diunduh 2014 Nov 23]. Tersedia pada: http://www.elburg global.nl/vegetable-fats/palm-oil/.

Giannoccaro, I., Pontrandolfo, P. 2004. Supply chain coordination by revenue sharing contracts. International Journal of Production Economics. 89(2): 131-139.

Gunawan, S., Kasim, N. S., Ju, Y. H. 2008. Separation and purification of squalene from soybean oil deodorizer distillate. Separation and Purification Technology. 60(2) : 128-135.

Haas, M. J. 2006. Improving the economic of biodiesel production hrough the use of low value lipids as feedstocks: vegetable oil soapstock. Fuel Processing Technology. 86(10): 10871096.

Hayyan, A., Mjalilli, F. S., Hashim, M.A., Hayyan, M., Al-Nashet, I. M. 2013. Conversion of free fatty acid in low grade crude palm oil to methyl esters for biodiesel production using chromosulfuric acid. Bulgarian Chemical Communication. 45(3): 394-399.

Idoko, O., Bwai, M. D., Emmanuel, S. A., Thomas, S. A. 2013. Effect of bleaching and degumming on the physicochemical properties and antioxidant activity of palm oil. Engineering and Applied Scinces. 2(5) :343-345. 
Igor, N., Susana, L. S., Marly, C., Otávio, L. B., Márcio, F., Marta, A. 2011. Enzymatic biodiesel synthesis using a byproduct obtained from palm oil refining. Enzyme Research. 81(1): 823.

Ira Desri, Rahmi, Neswati. 2013. The influence of molar ratio of methanol to PFAD and esterification reaction time towards biodiesel characteristics palm fatty acids distillate produced. Journal Advance Science Engineering Information Technology. 3(5): 9-13. ISSN:2088-5334.

Ivanoui, A., SchMeant, A., Peter, F., Rusnac, L. M., Ungurean, M. 2011. Comparative study on biodiesel synthesis from different vegetables oils. Chemical Bull POLITECHNICAL. 56(70): 94-98.

Jackson, M. C. 2003. System thinking: creative holism for managers. England (GB) : Jhon Wiley \& Sons. Inc.

Kumar, S., and Zander, M. 2007. Supply chain cost control using acitivity based management. France; Auerbach Publication

Lee, K. T., Ofori-Boateng, C. 2013. Sustainability of biofuel production from oil palm biomass. Singapore (SG): Springer Science and Media Bussiness.

Marchetti, M. J., Miguel, V. U., Errazu, A. F. 2008. Heterogeneous esterification of oil with high amount of free fatty acid. Fuel. 86(1): 906-910.

Mahlia, T. M. I., Ong, H. C., Masjuki, H. H. 2012. Techno economics analysis of biodiesel production from palm. Jatropha curcas. and Calophyllum inophyllum as biofuel. The Proceedings of 2 nd Annual International Conference Syiah Kuala University 2012 and 8th IMT-GT Uninet Biosciences Conference. Banda Aceh (ID).
Meher, L. C., Vidya, S. D., Naik, S. N. 2006. Technical aspects of biodiesel production by transesterification a review. Renewable and Sustainable Energy Reviews. 10(3): 248-268.

Melero, J. A., Bautista, L. F., Iglesias, J., Morales, Vazquez, R. S. 2014. Production of biodiesel from waste cooking oil in a continuous packed bed reactor with an agglomerated Zr-SBA15/bentonite catalyst. Applied Catalysis B: Environmental. 145(10): 197-204.

Moh, M. H., Yusof, M., Ooi, T. L., Tang, T. S. 1999. Unpublished Report. In: Ping BTY, Yusof M. 2009. Characteristics and properties of fatty acid distillates. Oil Palm Buletin. 59(11):5-11.

Morad, N. A., Madya, M., Mohd, R. 2006. Process design in degumming and bleaching of palm oil. Malaysia (MY):Centre of Lipids Engineering and Applied Science University of Technology.

Nagi, J., Ahmed, S. K., Nagi, F. 2008. Palm biodiesel an alternative green renewable energy for the energy demands of the future. ICCBT. 6(7): 79-94.

Oil World. 2014. Statistic for 17 Oil and Fats. Oil World Database Dec 2012. Oil World. Germany (DE): Oil World.

Paryanto, I., Kismanto, A., Amri, K., Solikhah, M. S. 2013. Some technical aspects for sustainable biodiesel production. International Jurnal on Advanced Science Engineering Information Technology. 4(2): 49-52.

Paudel, K. P., Lohr, L., Martin Jr, N. R. 1998. Optimal input cost sharing for tenants: implication for negotiating efficiency. Agricultural System. 57(1):1-11.

Purnomo, H. 2004. Pengantar teknik industri.Yogyakarta (ID): Graha llmu. 

Rahayu, S. K. 2009. Perpajakan Indonesia: Konsep dan aspek finansial. Yogyakarta (ID): Graha IImu.

Syafri, H. S. 2010. Teori akutansi. Jakarta (ID): Raja Grafindo Persada.

Taufiq-Yap, Y. H., Abdullah, N. F., Basri, M. 2011. Biodiesel production via transesterification of palm oil using $\mathrm{NaOH} / \mathrm{Al}_{2} \mathrm{O}_{3}$ Catalists. Sains Malaysiana. 40(6): 587-594.

Towler, G., Sinnott, R. 2008. Chemical engineering design. Paris (IT): Elsevier.

Verhe, R., Echim, C., Greyt, W. D., Stevens, C. 2011. Production of biodiesel via chemical catalytic conversion. In Handbook of biofuels production: Process and Technologies. Rafael J, Campelo J, Clark J Eds. 2011. Cambrige (UK): Woodhead Publishing.
Viswanath, P. V. 2000. Diversification and moral hazard in Roman Palestine evidence from agricultural contract law. International Review of Law and Economics. 20(3):353-369.

Wasson, C. S. 2006. System analysis design and development concepts. Principles and Practices. New Jersey (US): Jhon Willey \& Sons. Inc.

[WFP] World Food Programme. 2011. Technical specifications for the manufacture of palm olein. [Internet]. [diunduh 2014 Des 6]. Tersedia pada: http://documents.wfp.org.

Winarno, F. G. 2008. Kimia pangan dan gizi. Bogor: M-Brio.

Yang, W. 2011. A multi-objective optimization approach to allocate environment flows to the artifisially restored wetland of China's Yellow River Delta. Ecological Modelling. 222 (0): 261267 . Des 6. Tersedia pada: http:/www.tbs.go.tz. 